\title{
PENGGUNAAN MODEL PEMBELAJARAN NUMBERED HEADS TOGETHER NHT UNTUK MENINGKATKAN HASIL BELAJAR BAHASA INGGRIS SISWA PADA MATERI TEKS ANALYTICAL EXPOSITION KELAS XI IPS 2 SMA NEGERI 14 PEKANBARU TAHUN PELAJARAN 2015-2016 \\ (Use of NHT Numbered Heads Together Learning Model to Improve Student English Learning Outcomes on Analytical Exposition Text Material Class XI IPS 2 SMA Negeri 14 Pekanbaru Academic Year of 2015-2016)
}

\author{
Artati Arnis S.Pd, MM*) \\ NIP. 196807091994032007 \\ E-mail : angretajohn@gmail.com
}

*) Guru SMA Negeri 2 Pekanbaru

\begin{abstract}
This research was expected to provide benefits for: (1) For learners easier to understand and master English materials with Numbered Heads Together (NHT). (2) The results of this study are expected to provide input to teachers the importance of used NHT Learning Model to improve English learning outcomes. (3) The results of this study were expected to find out the learners' learning outcomes of English subjects delivered used NHT. This research took place in XI IPS 2 class SMAN 14 Pekanbaru Jl. Tengku Bey/Sei. Mintan I. The instrument of this study consists of observation sheet and tests. This study was a classroom action research consisting of four stages namely, planning, action, observation, and reflection. From the results of the study that the initial data was known that the students complete only 15 students with percentage of $42.86 \%$ while the student was not complete as many as 20 students with percentage of $57.14 \%$. With an average student score of 74.49 . On the completeness of student scores on the first cycle students expressed complete only as many as 24 students with percentage $85.71 \%$. While the students who do not complete as many as 11 students with a percentage of $31.43 \%$ with an average student score of 81.94. In this case from the number of students mastery expectations have not been achieved from the number of students as much as $70 \%$ of the number of students. On the completeness of student scores on the second cycle of students who expressed thoroughly only as many as 35 students with $100 \%$ percentage. While there are no students who were not complete with an average student score of 89.91. In this case from the number of students' mastery expectation had been achieved from $70 \%$ of the total number of students as 35 students expressed thoroughly so that in this case there was no need to take action back in the following cycle or research conducted only two cycles
\end{abstract}

Keywords: Learning Outcomes, Learning Model Numbered Heads Together (NHT) and English

\section{PENDAHULUAN}

Pendidikan adalah salah satu bentuk perwujudan kebudayaan manusia yang dinamis dan sarat perkembangan. Perubahan atau perkembangan pendidikan adalah hal yang memang seharusnya terjadi sejalan dengan perubahan budaya kehidupan Trianto, 2011:1. Pendidikan dan pengajaran adalah salah satu usaha yang bersifat sadar yang sistematis terarah pada perubahan tingkah laku menuju kedewasaan anak Sardiman, 2012:12. Pendidikan merupakan proses perubahan 
menuju pendewasaan, pencerdasan, dan pematangan diri Suhartono, 2007:80. Berhasil tidaknya pencapaian tujuan pendidikan ini banyak tergantung dari proses pembelajaran Sudjana, 2009:25. Dalam UU No. 20 Tahun 2003 tentang SISDIKNAS, bahwa pendidikan adalah usaha sadar dan terencana untuk mewujudkan suasana belajar dan proses pembelajaran agar peserta didik secara aktif mengembangkan potensi dirinya untuk memiliki kekuatan spiritual keagamaan, pengendalian diri, kepribadian, kecerdasan, akhlak mulia, serta keterampilan yang diperlukan dirinya, masyarakat, bangsa, dan negara.

Mengalami langsung apa yang sedang dipelajari akan mengaktifkan lebih banyak indera daripada hanya mendengarkan guru menerangkan. Hal ini menunjukkan bahwa jika mengajar dengan banyak berceramah, maka tingkat pemahaman peserta didik hanya $20 \%$, tetapi jika peserta didik diminta untuk melakukan sesuatu sambil mengkomunikasikan, tingkat pemahaman peserta didik dapat mencapai sekitar 90\% Yamin, 2015:192. Pada dasarnya semua anak memiliki potensi untuk mencapai kompetensi sehingga perlu adanya kreatifitas guru untuk membantu mencapainya.

Hasil observasi menunjukan bahwa proses pembelajaran masih monoton dan konvensional. Siswa mendengarkan dan mencatat lalu latihan soal. Sehingga hasil belajar Bahasa Inggris siswa kelas XI IPS 2 dalam memahami kemampuan membaca dengan kriteria ketuntasan minimal 82 ternyata masih ada siswa yang mendapatkan nilai dibawah 82 sebanyak 15 orang dari 35 orang orang, hal ini disebabkan oleh 1) Siswa kurang aktif dalam pembelajaran, terlihat dari jarangnya siswa bertanya dalam pembelajaran. 2) Masih rendahnya kategori hasil belajar Bahasa Inggris. 3) Belum optimalnya model pembelajaran yang diterapkan guru dalam meningkatkan hasil belajar Bahasa Inggris siswa. 4) Guru belum pernah menerapkan model pembelajaran kooperatif tipe NHT

Salah satu cara yang dapat
digunakan oleh meningkatkan motivasi, aktifitas dan hasil belajar siswa adalah penerapan pembelajaran kooperatif. Pembelajaran kooperatif merupakan salah satu model pembelajaran dengan membentuk siswa belajar dalam kelompok-kelompok kecil Slavin, 2009:45. Pembelajaran kooperatif yang merangsang keaktifan siswa adalah model pembelajaran Numbered Heads Together NHT. Model pembelajaran NHT adalah model pembelajaran yang lebih memungkinkan siswa untuk lebih aktif dan bertanggung jawab penuh untuk memahami materi pelajaran baik secara kelompok maupun individual Kusumojanto 2009:46. Pada proses pembelajaran siswa lebih bertanggungjawab terhadap tugas yang diberikan karena dalam pembelajaran kooperatif tipe NHT siswa dalam kelompok diberi nomor yang berbeda. Setiap siswa diwajibkan untuk menyelesaikan soal yang sesuai dengan nomor anggota mereka. Dengan pembelajaran semacam ini siswa dapat melakukan diskusi dengan sungguhsungguh dan siswa yang pandai dapat mengajari siswa yang kurang pandai sehingga meminimalkan tingkat kesulitan belajar.

Menurut Lie 2007:59, bahwa teknik Numbered Heads Together memberikan kesempatan kepada siswa untuk membagikan ide dan mempertimbangkan jawaban yang paling tepat. Teknik ini juga mendorong siswa untuk meningkatkan semangat kerja sama. Teknik ini bisa digunakan untuk setiap mata pelajaran dan semua tingkatan usia. Tujuan penelitian ini adalah untuk mengetahui Penggunaan model pembelajaran Numbered Heads 
Together NHT untuk meningkatkan hasil belajar Bahasa Inggris siswa pada materi teks analytical exposition kelas XI IPS 2 SMA Negeri 14 Pekanbaru Tahun Pelajaran 2015-2016

\section{KAJIAN PUSTAKA \\ NHT Numbered Heads Together}

\author{
Miftahul Huda 2012:130
} menyatakan bahwa pada dasarnya NHT Numbered Heads Together merupakan varian dari diskusi kelompok, teknik pelaksanaanya hampir sama dengan diskusi kelompok. Menurut Robert E. Slavin 1995 dalam Miftahul Huda 2012:130. Metode ini cocok untuk memastikan akuntabilitas individu dalam diskusi kelompok. Pembelajaran kooperatif tipe Numbered Heads Together dikembangkan oleh Spencer Kagan 1993 untuk melibatkan lebih banyak peserta didik dalam menelaah materi yang tercakup dalam suatu pelajaran dan mengecek pemahaman mereka terhadap isi pelajaran tersebut Trianto, 2009:82. Menurut Miftahul Huda 2012:87, umumnya NHT digunakan untuk melibatkan peserta didik dalam penguatan pemahaman pembelajaran atau mengetahui pemahaman peserta didik terhadap materi pembelajaran.

Numbered Head Together dikembangkan oleh Spencer Kagan 1992. Metode ini memberikan kesempatan kepada siswa untuk saling membagikan ide-ide dan mempertimbangkan jawaban yang paling tepat terhadap pertanyaan atau masalah yang sedang dihadapi. Langkah-langkah yang dilakukan dalam pembelajaran kooperatif dengan metode ini menurut Ibrahim, dkk 2009:28 ada empat langkah yaitu:penomoran Numbering , mengajukan pertanyaan Questioning, berfikir bersama Head Together, dan menjawab Answering.

Menurut Lie 2007:60, langkah pembelajaran Numbered Heads Together adalah 1) Siswa dibagi menjadi beberapa kelompok. Setiap siswa dan kelompok mendapatkan nomor. 2) Guru memberikan tugas dan masing-masing kolompok mengerjakannya. 3) Kelompok memutuskan jawaban yang dianggap paling benar dan memastikan setiap kelompok mengetahui jawaban ini. 4) Guru memanggil salah satu nomor. Nomor siswa yang dipanggil melaporkan hasil kerja mereka.

Berdasarkan beberapa pendapat para ahli tersebut, peneliti menetapkan langkah-langkah pembelajaran kooperatif NHT, yaitu 1) Guru menjelaskan materi yang akan dipelajari; 2) Guru memberi kesempatan kepada beberapa siswa untuk menyelesaikan soal berkaitan dengan materi; 3) Siswa dibagi menjadi beberapa kolompok. Setiap siswa dan kelompok mendapatkan nomor; 4) Guru memberikan tugas dan masing-masing kolompok mengerjakannya; 5) Guru Meminta kelompok memutuskan jawaban yang dianggap paling benar dan memastikan setiap kelompok mengetahui jawaban ini, dan memanggil salah satu nomor. Siswa dengan nomor yang dipanggil melaporkan hasil kerja mereka.

Menurut Ahmad Zuhdi 2010:65 kelebihan Numbered Heads Together adalah setiap siswa menjadi siap semua, dapat melakukan diskusi dengan sungguh-sungguh, dan siswa yang pandai dapat mengajari siswa yang kurang pandai. Adapun kelemahannya adalah kemungkinan nomor yang dipanggil, dipanggil lagi oleh guru, dan tidak semua anggota kelompok dipanggil oleh guru.

\section{Penelitian Tindakan Kelas}

Model Pembelajaran dalam penelitian ini adalah Penelitian Tindakan Kelas PTK. Menurut Zainal Aqib 2008:3 Penelitian Tindakan Kelas adalah suatu penelitian yang dilakukan oleh guru melalui refleksi diri dengan tujuan untuk 
memperbaiki kinerjanya sehingga hasil belajar meningkat. Model Pembelajaran penelitian tindakan yang dilakukan dalam penelitian ini adalah Model Pembelajaran spiral dari Kemmis dan Taggart yang terdiri dari beberapa siklus tindakan. Dimana setiap siklus tersebut terdiri 4 tahapan yang meliputi perencanaan, pelaksanaan tindakan, observasi dan refleksi Arikunto, 2008:74.

\section{METODOLOGI PENELITIAN}

Penelitian ini bertempat di kelas XI IPS 2 SMAN 14 Pekanbaru Jl. Tengku Bey / Sei. Mintan I. Penelitian dilaksanakan pada semester ganjil pada Tahun Pelajaran 2015-2016. Rancangan penelitian ini terdiri dari Perencanaan, Tindakan, Observasi, dan Refleksi. Subjek penelitian ini adalah siswa kelas XI IPS 2 SMAN 14 Pekanbaru Tahun ajaran 2015-2016 sebanyak 35 orang. Sedangkan yang menjadi objek penelitian adalah Hasil Belajar Siswa XI IPS 2 SMAN 14 Pekanbaru Tahun Ajaran 2015-2016. Sumber Data adalah Tes Hasil dan Lembar Observasi. Teknik pengumpulan data menggunakan Tes dan Observasi. Dalam penelitian ini teknik analisis data menggunakan rumus Warsito, 1992:59.

$$
P=\frac{F}{N} \times 100 \%
$$

\section{HASIL PENELITIAN DAN PEMBAHASAN}

Berdasaran hasil penelitian yang telah dilakukan terlihat perkembangan yang signifikan. Pada Siklus I Pertemuan 1 Aktivitas pembelajaran berada pada kategori sedang dengan rata-rata skor sebesar $62.5 \%$. Hal ini terjadi karena siswa masih banyak belum terbiasa dengan pembelajaran aktif karena siswa terbiasa dengan pembelajaran yang terpusat pada guru. Disisi lain banyaknya siswa yang tidak biasa mengakibatkan suasana kelas yang gaduh sehingga guru meningkatkan penguasaan kelas terhadap siswa sehingga kurang memberikan bimbingan pada siswa yang bersemangat dengan pembelajaran aktif.

Pada Siklus I Pertemuan 2 Aktivitas pembelajaran berada pada kategori baik dengan rata-rata skor sebesar $70.8 \%$. Hal ini terjadi karena siswa sudah mulai terbiasa dengan pembelajaran aktif karena siswa terbiasa dan pembelajaran tidak lagi terpusat pada guru. Disisi lain masih banyaknya siswa yang tidak biasa mengakibatkan suasana kelas yang gaduh. Penguasaan kelas terhadap siswa masih tinggi namun bimbigan yang guru kepada siswa sudah mulai ditingkatkan dan membaik. Pada Siklus I Pertemuan 2 Aktivitas pembelajaran berada pada kategori sangat baik dengan rata-rata skor sebesar 91.7\%. Hal ini terjadi karena siswa semakin bersemangat dengan pembelajaran aktif yang diterapkan sehingga terjadi peningkatan aktifitas pembelajaran. Pada Siklus II Pertemuan 2 Aktivitas pembelajaran berada pada kategori sangat baik dengan rata-rata skor sebesar $95.8 \%$. Hal ini terjadi karena siswa semakin bersemangat dengan pembelajaran aktif yang diterapkan sehingga terjadi peningkatan aktifitas pembelajaran.

Perkembangan siswa juga dapat dilihat dari nilai diskusi kelompok yang dilakukan oleh siswa dalam pembelajaran yang dilakukan. Terlihat pada Siklus I Pertemuan 1 kelompok tuntas sebanyak 2 kelompok dengan persentase $22.22 \%$. Sedangkan kelompok tidak tuntas sebanyak 7 kelompok dengan persentase $77.78 \%$. Dengan rata-rata nilai sebesar 76.22. Hal ini terjadi karena hanya beberapa siswa yang bersemangat dengan pembelajaran aktif yang diterapkan. Sedang siswa lain tidak bersemangat karena tidak terbiasa dengan pembelajaran yang dilakukan. Namun jika dilihat dari rata-rata nilai siswa terlihat ada kemajuan yakni 76. 22. 
Pada Siklus I Pertemuan 2 kelompok tuntas meningkat menjadi 4 kelompok dengan persentase $44.44 \%$. Sedangkan kelompok tidak tuntas sebanyak 5 kelompok dengan persentase $55.56 \%$. Dengan rata-rata nilai sebesar 83.11. Hal ini terjadi karena siswa sudah mulai bersemangat dengan pembelajaran aktif yang diterapkan. Siswa lain tidak bersemangat karena tidak terbiasa dengan pembelajaran yang dilakukan. Namun ada kemajuan rata-rata nilai siswa dari 76. 22 menjadi 83.11.

Pada Siklus II Pertemuan 1 kelompok tuntas meningkat menjadi 7 kelompok dengan persentase $77.78 \%$. Sedangkan kelompok tidak tuntas sebanyak 2 kelompok dengan persentase $22.22 \%$. Dengan rata-rata nilai sebesar 76.22. Hal ini terjadi karena hanya beberapa siswa yang bersemangat dengan pembelajaran aktif yang diterapkan. Sedang siswa lain tidak bersemangat karena tidak terbiasa dengan pembelajaran yang dilakukan. Rata-rata nilai terlihat ada kemajuan menjadi 86.78.

Pada Siklus II Pertemuan 2 kelompok tuntas meningkat menjadi 9 kelompok dengan persentase $100 \%$. Dalam pertemuan kali ini tidak ada kelompok yang tidak tuntas Dengan ratarata nilai sebesar 91. Hal ini terjadi karena semua kelompok telah paham dan terbiasa dengan tindakan yang diberikan dan siswa semakin bersemangat saat pembelajaran berlangsung sehingga proses pembelajaran berjalan dengan lancar. Diketahui pada data awal diketahui bahwa siswa tuntas hanya sebanyak 15 orang dengan persentase $42.86 \%$ sedangkan siswa tidak tuntas sebanyak 20 orang dengan persentase $57.14 \%$. Dengan rata-rata sebesar 74.49. pada ketuntasan nilai siswa pada siklus I siswa yang dinyatakan tuntas hanya sebanyak 24 orang dengan persentase $85.71 \%$. Sedangkan siswa yang tidak tuntas sebanyak11 orang dengan persentase $31.43 \%$ dengan rata-rata sebesar 81.94. Jumlah harapan ketuntasan siswa belum tercapai sebanyak $70 \%$. pada ketuntasan nilai siswa pada siklus II siswa yang dinyatakan tuntas hanya sebanyak 35 orang dengan persentase $100 \%$. Sedangkan siswa tidak ada siswa yang tidak tuntas dengan rata-rata sebesar 89.91. Ketuntasan siswa telah tercapai dari $70 \%$ jumlah siswa sebanyak 35 orang yang dinyatakan tuntas sehingga tidak perlu dilakukan tindakan pada siklus berikut atau penelitian yang dilakukan hanya dua siklus.

\section{PENUTUP \\ Simpulan}

Pada Siklus I Pertemuan 1 Aktivitas pembelajaran berada pada kategori sedang dengan rata-rata skor sebesar $62.5 \%$. pada Siklus I Pertemuan 2 Aktivitas pembelajaran berada pada kategori baik dengan rata-rata skor sebesar 70.8\% . pada Siklus I Pertemuan 2 Aktivitas pembelajaran berada pada kategori sangat baik dengan rata-rata skor sebesar $91.7 \%$. pada Siklus II Pertemuan 2 Aktivitas pembelajaran berada pada kategori sangat baik dengan rata-rata skor $95.8 \%$.

Pada Siklus I Pertemuan 1 kelompok tuntas sebanyak 2 kelompok dengan persentase $22.22 \%$. Sedangkan kelompok tidak tuntas sebanyak 7 kelompok dengan persentase $77.78 \%$. Dengan rata-rata nilai sebesar 76.22. pada Siklus I Pertemuan 2 kelompok tuntas meningkat menjadi 4 kelompok dengan persentase $44.44 \%$. Sedangkan kelompok tidak tuntas sebanyak 5 kelompok dengan persentase $55.56 \%$. Dengan rata-rata sebesar 83.11. pada Siklus II Pertemuan 1 kelompok tuntas meningkat menjadi 7 kelompok dengan persentase $77.78 \%$. Sedangkan kelompok tidak tuntas sebanyak 2 kelompok dengan persentase $22.22 \%$. Dengan rata-rata sebesar 76.22. Pada Siklus II Pertemuan 2 kelompok tuntas 
meningkat menjadi 9 kelompok dengan persentase $100 \%$. Dalam pertemuan kali ini tidak ada kelompok yang tidak tuntas Dengan rata-rata nilai sebesar 91.

Pada data awal diketahui bahwa siswa tuntas hanya sebanyak 15 orang dengan persentase $42.86 \%$ sedangkan siswa tidak tuntas sebanyak 20 orang dengan persentase $57.14 \%$. Dengan ratarata sebesar 74.49. pada ketuntasan nilai siswa pada siklus I siswa yang dinyatakan tuntas hanya sebanyak 24 orang dengan persentase $85.71 \%$. Sedangkan siswa yang tidak tuntas sebanyak11 orang dengan persentase $31.43 \%$ dengan rata-rata sebesar 81.94. Jumlah harapan ketuntasan siswa belum tercapai sebanyak $70 \%$. Pada ketuntasan nilai siswa pada siklus II siswa yang dinyatakan tuntas hanya sebanyak 35 orang dengan persentase $100 \%$. Sedangkan siswa tidak ada siswa yang tidak tuntas dengan rata-rata sebesar 89.91. Jumlah harapan ketuntasan siswa telah tercapai dari $70 \%$ jumlah siswa sebanyak 35 orang yang dinyatakan tuntas sehingga tidak perlu dilakukan tindakan kembali pada siklus berikut atau penelitian dilakukan hanya dua siklus.

\section{REFERENSI}

Ahmad Zuhdi. 2010.Guru Idola. Yogyakarta:Gen-K Publisher

Aqib, Zainal. 2008. Penelitian Tindakan Kelas. Bandung:Yrama Widya.

Arikunto, Suharsimi., dkk. 2008. Penelitian Tindakan Kelas. Jakarta:Bumi. Aksara.

Dimyati Dan Mudijono. 2000. Belajar dan Pembelajaran. Jakarta : Penerbit Rineka Cipta

Djamarah, Syaiful Bahri. 2002. Psikologi Belajar. Jakarta:Rineka Cipta

Djamarah, Syaiful Bahri. 2006. Strategi Belajar Mengajar. Jakarta:Rineka Cipta.
GBHN. 1999. Tahun

eISSN:2579-9525

Surabaya :Apollo

Hamalik, Oemar. 2003. Kurikulum dan Pembelajaran. Jakarta:Bumi Aksara.

Hanafiah, Nanang. dan Cucu, Suhana. 2009. Konsep Strategi Pembelajaran. Bandung: Refika Aditama.

Harsanto, 2007. Pengelolaan Kelas Yang Dinamis.

BaruPembelajaran

Paradigma

Kompetensi Siswa Yogyakarta.

Kanisius.

Ibrahim, dkk 2009. Kurikulum dan Pembelajaran. Jakarta:PT Raja Grafindo Persada

Jihad dan Abdul.2013. Evaluasi Pembelajaran.Yogyakarta:Multi Pressindo

Kusumojanto \& Herawati. 2009. Penerapan Pembelajaran Kooperatif Model NHT untuk Meningkatkan Hasil Belajar. Jurnal Penelitian Kependidikan. 19, 1, 83-89.

Lie, Anita. 2007. Cooperative Learning. Jakarta:Grasindo

Marsigit. 2005. Langkah-langkah Pembelajaran Jakarta:Yudhistira

Miftahul Huda 2012. Cooperative Learning, Teori dan Aplikasi PAIKEM. Yogyakarta: Pustaka Pelajar.

Nana Sudjana. 2011. Pekategorian Hasil Proses Belajar Mengajar. Bandung:PT. Remaja Rosydakarya.

Ngalim Purwanto. 2006. Psikologi Pendidikan. Bandung :PT. Remaja Rosdakarya.

Nurgiantoro, Burhan. 1988. Pekategorian dalam Pengajaran Bahasa dan Sastra. Yogyakarta.

Purwanto, 1990. Evaluasi Hasil Belajar. Yogyakarta:Pustaka Pelajar 
Rosyada, Dede. 2004. Paradigma Pendidikan Demokratis. Jakarta : Kencana

Sabri, Ahmad. 2005. Strategi Belajar Mengajar Dan Micro Teaching. Jakarta:Ciputat Press

Sagala, Syaiful. 2003. Konsep dan Makna Pembelajaran. Bandung:CV Alfabeta

Sanjaya, Winna. 2008 Strategi Pembelajaran Berorientasi Standar Proses Pendidikan. Jakarta :Kencana Prenada Media Group

Sanjaya. 2015. Faktor - faktor yang Mempengaruhi Hasil belajar. Jakarta: Prenada

Sanjaya. Wina. 2007. Strategi Pembelajaran Berorientasi Standar Proses Pendidikan. Jakarta:Kencana.

Sardiman. 2012. Interaksi dan Motivasi Belajar Mengajar. Jakarta : Rajawali Pers.

Slameto. 2003. Belajar dan Faktorfaktor yang Mempengaruhinya. Jakarta:Rineka Cipta.

Slavin, Robert E. 2009. Cooperative Learning Teori, Riset, Praktik. Bandung:Nusa Media.

Sudjana Nana. 2009. Pekategorian Hasil Proses Belajar Mengajar. Bandung:Remaja Rosdakarya.

Sudjana. 2000. Metode Statistik. Tarsito:Bandung

Sugihartono, dkk. 2007. PsikologiPendidikan.Yogyakarta:UN Y Press

Suhartono, Suparlan. 2007. Filsafat Pendidikan. Yogyakarta:Kanisius.

Suparlan. 2005. Menjadi Guru Efektif. Yogyakarta:Hikayat Publishing,
Susanto. 2014. Teori Belajar dan Pembelajaran di Sekolah Dasar. Jakarta:Kencana Prenada Media Group

Syah, Muhibbin. 2000. Psikologi Pendidikan. Bandung:Remaja Rosda Karya.

Tirtarahardja. 2005. Umar Pengantar Pendidikan. Jakarta:PT Rineka Cipta

Trianto. 2009. Mendasain Model Pembelajaran Inovatif-Progresif. Prestasi. Pustaka. Jakarta:Bumi Aksara

Trianto. 2011. Model Pembelajaran Terpadu. Jakarta:Bumi Aksara

Undang-Undang No. 20 Tahun 2003 Tentang Sisdiknas

Wahab, Solichin. 2008. Analisis Kebijaksanaan Dari Formulasi Ke. Implementasi Kebijaksanaan Negara. Edisi Kedua. Jakarta:PT. Bumi Aksara

Warsito, Hermawan. 1992. Pengantar Metodologi Penelitian. Jakarta: Gramedia. Pustaka Utama

Wina Sanjaya. 2009. Strategi Pembelajaran Berorientasi Standar Proses Pendidikan. Jakarta :Kencana Prenada Media Group.

Yamin, Martinis dan Bansu I Ansari. 2015. Taktik Mengembangkan Kemampuan Individual Siswa. Jakarta:Gaung Persada Press

Zainal Aqib. 2008. Penelitian Tindakan Kelas untuk Guru. Bandung:Yrama Widya 